\title{
Lanostane- and cycloartane-type triterpenoids from Abies balsamea oleoresin
}

\author{
Serge Lavoie ${ }^{\ddagger 1}$, Charles Gauthier ${ }^{\ddagger 1,2}$, Jean Legault ${ }^{1}$, Sylvain Mercier ${ }^{1}$, \\ Vakhtang Mshvildadze ${ }^{1}$ and André Pichette ${ }^{* 1}$
}

\section{Full Research Paper}

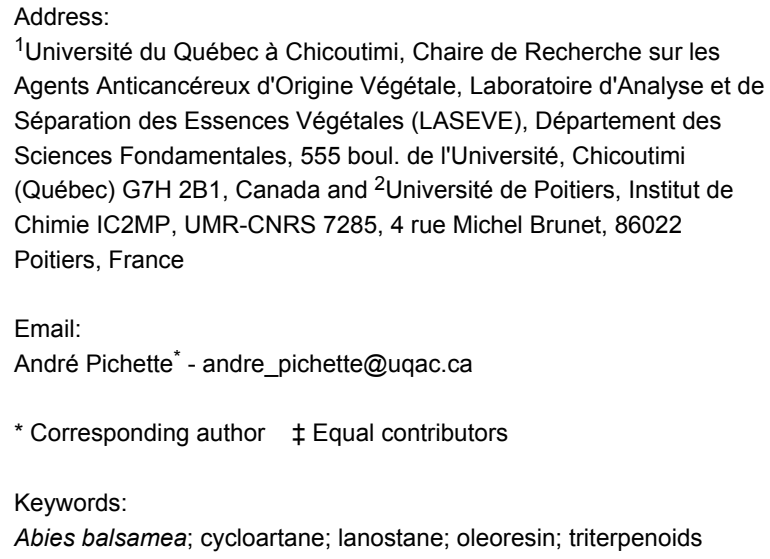

${ }^{1}$ Université du Québec à Chicoutimi, Chaire de Recherche sur les Agents Anticancéreux d'Origine Végétale, Laboratoire d'Analyse et de Séparation des Essences Végétales (LASEVE), Département des Sciences Fondamentales, 555 boul. de l'Université, Chicoutimi (Québec) G7H 2B1, Canada and 2Université de Poitiers, Institut de Chimie IC2MP, UMR-CNRS 7285, 4 rue Michel Brunet, 86022 Poitiers, France

Email:

André Pichette* - andre_pichette@uqac.ca

* Corresponding author $\ddagger$ Equal contributors

Keywords:

Abies balsamea; cycloartane; lanostane; oleoresin; triterpenoids

Beilstein J. Org. Chem. 2013, 9, 1333-1339.

doi:10.3762/bjoc. 9.150

Received: 15 April 2013

Accepted: 12 June 2013

Published: 04 July 2013

Associate Editor: A. Kirschning

(C) 2013 Lavoie et al; licensee Beilstein-Institut. License and terms: see end of document. 
phytochemical study of $A$. balsamea oleoresin, which led to the isolation and structure elucidation of three 3,4-seco-lanostanetype triterpenoids 1-3, one cycloartane-type triterpenoid $\mathbf{4}$ and fourteen known terpenoids. The antibacterial (E. coli and S. aureus) and cytotoxic (A549, DLD-1 and WS1) activities of the isolated compounds are also reported.

\section{Results and Discussion}

The oleoresin of $A$. balsamea $\left(1^{\text {st }}\right.$ lot) was fractionated by silica gel column chromatography with hexanes/EtOAc $(100: 0 \rightarrow$ 93:7) and $\mathrm{MeOH}$ as eluent. Both hexanes/EtOAc 93:7 and
$\mathrm{MeOH}$ fractions were combined and concentrated under reduced pressure. Purification of this extract using a combination of silica gel or polyamide column chromatography and reversed phase $\mathrm{C}_{18}$ HPLC resulted in the isolation of three new (1-3) and six known terpenoids (Figure 1). In another experiment, oleoresin $\left(2^{\text {nd }}\right.$ lot $)$ was triturated with hexanes. The precipitate was subjected to successive silica gel column chromatography followed by reversed phase $\mathrm{C}_{18}$ HPLC to give one new (4) as well as three known terpenoids. Similarly, purification of the filtrate afforded five known terpenoids. Based on their spectroscopic data (IR, MS and NMR) and comparison

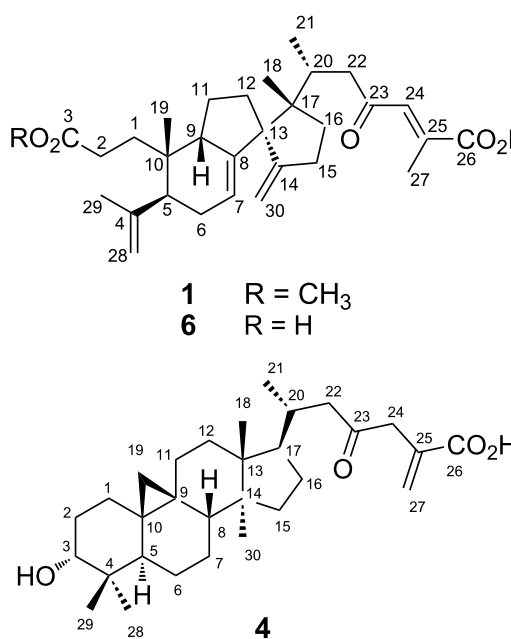<smiles>C=C(C)[C@H]1CC=C2[C@@H]3CC[C@H]([C@H](C)/C=C4/C=C(C)C(=O)O4)[C@@]3(C)CC[C@]2(C)[C@]1(C)CCC(=O)O</smiles>

8<smiles>C=C(C)[C@H]1C=CC2=C3CC[C@](C)([C@H](C)CC4C[C@@H](C)C(=O)O4)[C@@]3(C)CC[C@]2(C)[C@]1(C)CCC(=O)O</smiles>

11<smiles></smiles>

$15 \mathrm{R}=\mathrm{H}$

$16 \quad \mathrm{R}=\mathrm{CH}_{3}$

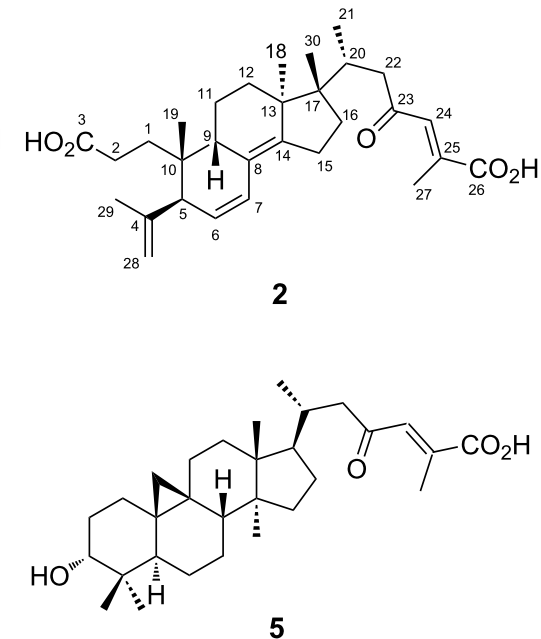

5<smiles>C=C(C)[C@H]1CC=C2[C@]3(C)CCC([C@H](C)CC(=O)C[C@H](C)C(=O)O)[C@@]3(C)CC[C@]2(C)[C@]1(C)CCC(=O)O</smiles>

9<smiles>C=C(C)[C@H]1CC=C2[C@]3(C)CCC([C@H](C)CC/C=C(\C)C(=O)O)[C@@]3(C)CC[C@]2(C)[C@]1(C)CCC(=O)O</smiles>

12<smiles>CC(C=O)=CC[C@H]1[C@](C)(O)CC[C@H]2C(C)(C)CCC[C@]21C</smiles>

17<smiles>C=C(C)[C@H]1CC=C2[C@@H]3CC[C@H]([C@H](C)CC(=O)/C=C(\C)C(=O)O)[C@@]3(C)CC[C@]2(C)[C@]1(C)CCC(=O)O</smiles>

3

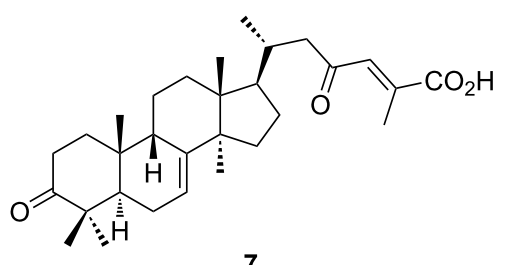<smiles>C=C(C)[C@H]1CC=C2[C@](C)(CC[C@]3(C)C([C@H](C)CC4C[C@H](C)C(=O)O4)CC[C@@]23C)C1(C)CCC(=O)O</smiles>

10<smiles>[R]C1(C)CCC[C@@]2(C)[C@H]1CCC1=CC(=O)CC[C@@H]12</smiles>

$13 \mathrm{R}=\mathrm{CHO}$

$14 \mathrm{R}=\mathrm{CO}_{2} \mathrm{CH}_{3}$<smiles>CC(=O)/C=C/C1[C@@]2(C)CCC[C@H](C)[C@@H]2CC[C@@]1(C)O</smiles>

18

Figure 1: Structures of isolated compounds 1-18. 
with literature values, the structures of the known compounds were elucidated as awashishinic acid (5) [7], abiesonic acid (6) [6], firmanoic acid (7) [8], (22Z)-3,4-seco-9 $\beta H$-lanosta4(28),7,22,24-tetraen-23,26-olid-3-oic acid (8) [9], (25R)-3,4seco-9 $\beta H$-lanosta-4(28),7-diene-3,26-dioic acid (9) [10], abiesolidic acid (10) [10,11], (23R,25R)-3,4-seco-17,14-friedo9ßH-lanosta-4(28),6,8(14)-trien-26,23-olid-3-oic acid (11) [10], (24E)-3,4-seco-9 $\beta H$-lanosta-4(28),7,24-triene-3,26-dioic acid (12) [12], abiesanordine C (13) [13], methyl 13-oxo-podocarp8(14)-en-15-oate (14) [14], 15-hydroxydehydroabietic acid (15) [15], methyl 15-hydroxydehydroabietate (16) [16], (12E)-8hydroxy-15-nor-12-labden-14-al (17) [17] and 8-hydroxy14,15-dinor-11-labden-13-one (18) $[13,18]$ (Figure 1). ${ }^{1} \mathrm{H}$ and ${ }^{13} \mathrm{C}$ NMR spectroscopic data of known compounds $(\mathbf{5}-\mathbf{1 8})$ are given in Supporting Information File 1.

Compound 1 was isolated as a white amorphous powder. Its molecular formula was established as $\mathrm{C}_{31} \mathrm{H}_{44} \mathrm{O}_{5}$ from the $[\mathrm{M}+\mathrm{H}]^{+}$peak at $m / z 497.3261$ (calcd 497.3262) in the positive HRESIMS, indicating ten degrees of unsaturation. The IR spectrum displayed strong absorption bands at 1692 and $1736 \mathrm{~cm}^{-1}$ indicative of carboxylic acid functionalities. The ${ }^{13} \mathrm{C}$ NMR and DEPT spectroscopic data (Table 1) exhibited 31 carbons including one carbonyl carbon at $\delta_{\mathrm{C}} 202.4$, and two carboxylic carbons at $\delta_{\mathrm{C}} 172.4$ and 174.8. The ${ }^{1} \mathrm{H}$ NMR data (Table 2) exhibited six olefinic signals at $\delta_{\mathrm{H}} 4.73(\mathrm{~s}), 4.77(\mathrm{~s}), 4.78(\mathrm{~s})$, $4.86(\mathrm{~s}), 5.48(\mathrm{dd}, J=6.2,3.1 \mathrm{~Hz})$ and $7.11(\mathrm{br} \mathrm{s})$, one methoxy methyl at $\delta_{\mathrm{H}} 3.67(\mathrm{~s})$, four tertiary methyl at $\delta_{\mathrm{H}} 0.90(\mathrm{~s})$, $0.92(\mathrm{~s}), 1.75(\mathrm{~s})$ and $2.18(\mathrm{~s})$ and one secondary methyl at $\delta_{\mathrm{H}}$ $0.85(\mathrm{~d}, J=6.4 \mathrm{~Hz})$. Detail analysis of the above NMR information, together with ${ }^{1} \mathrm{H}-{ }^{1} \mathrm{H}$ COSY, HSQC and HMBC analyses indicated that $\mathbf{1}$ shares the same structure with abiesonic acid (6), previously isolated from A. balsamea [6], but with an additional methoxy group. An HMBC cross-peak between this methyl signal and the carbon at $\delta_{\mathrm{C}} 174.8(\mathrm{C}-3)$ allowed the assignment of compound $\mathbf{1}$ as (-)-rel-abiesonic acid 3-methyl ester.

Compound 2, obtained as a white amorphous powder, possessed a molecular formula of $\mathrm{C}_{30} \mathrm{H}_{42} \mathrm{O}_{4}$ with ten degrees of unsaturation based on the $[\mathrm{M}+\mathrm{H}]^{+}$peak at $\mathrm{m} / z 483.3087$ (calcd 483.3105) in the positive HRESIMS. The IR absorption bands showed the presence of carboxylic acid $\left(1702 \mathrm{~cm}^{-1}\right)$ and olefin $\left(1635 \mathrm{~cm}^{-1}\right)$ functionalities. The ${ }^{13} \mathrm{C}$ NMR spectroscopic data of 2 (Table 1) displayed 30 carbon signals, which by the assistance of a DEPT experiment, were identified as six methyl, seven $s p^{3}$ methylene and three $s p^{3}$ methine groups, three $s p^{3}$ quaternary carbon atoms, one $s p^{2}$ methylene and three $s p^{2}$ methine groups, and seven $s p^{2}$ quaternary carbon atoms. A ${ }^{1} \mathrm{H}-{ }^{1} \mathrm{H}$ COSY experiment provided correlations from $\mathrm{H}_{2}-1$ to $\mathrm{H}_{2}-2, \mathrm{H}-6$ to $\mathrm{H}-5$ and $\mathrm{H}-7, \mathrm{H}_{2}-11$ to $\mathrm{H}-9$ and $\mathrm{H}_{2}-12, \mathrm{H}_{2}-15$ to
Table 1: ${ }^{13} \mathrm{C}$ NMR spectroscopic data $\left(100 \mathrm{MHz} \mathrm{CDCl}_{3}\right)$ of compounds 1-4.

\begin{tabular}{|c|c|c|c|c|}
\hline Position & 1 & 2 & 3 & 4 \\
\hline 1 & 30.5 & 28.3 & 28.8 & 27.5 \\
\hline 2 & 29.2 & 29.8 & 29.2 & 28.5 \\
\hline 3 & 174.8 & 181.6 & 180.8 & 77.1 \\
\hline 4 & 149.2 & 145.6 & 149.7 & 39.5 \\
\hline 5 & 44.0 & 50.6 & 45.3 & 41.1 \\
\hline 6 & 30.9 & 127.0 & 29.7 & 21.1 \\
\hline 7 & 122.4 & 125.2 & 118.0 & 25.6 \\
\hline 8 & 143.4 & 125.4 & 146.3 & 48.0 \\
\hline 9 & 49.5 & 39.4 & 38.6 & 19.7 \\
\hline 10 & 36.9 & 37.0 & 36.3 & 26.5 \\
\hline 11 & 22.5 & 19.6 & 18.5 & 26.2 \\
\hline 12 & 31.2 & 32.0 & 33.8 & 32.8 \\
\hline 13 & 63.5 & 47.4 & 43.8 & 45.4 \\
\hline 14 & 160.9 & 146.2 & 51.7 & 49.0 \\
\hline 15 & 27.8 & 23.9 & 34.0 & 35.4 \\
\hline 16 & 36.1 & 36.3 & 28.5 & 28.3 \\
\hline 17 & 50.2 & 49.1 & 53.1 & 52.2 \\
\hline 18 & 17.7 & 21.9 & 21.7 & 18.1 \\
\hline 19 & 24.7 & 21.8 & 24.1 & 29.8 \\
\hline 20 & 33.8 & 35.1 & 33.3 & 32.9 \\
\hline 21 & 16.4 & 15.9 & 19.5 & 19.3 \\
\hline 22 & 48.3 & 48.9 & 51.9 & 50.0 \\
\hline 23 & 202.4 & 202.5 & 202.4 & 207.6 \\
\hline 24 & 134.9 & 133.0 & 134.4 & 46.1 \\
\hline 25 & 138.7 & 140.4 & 139.3 & 133.9 \\
\hline 26 & 172.4 & 173.4 & 172.8 & 170.8 \\
\hline 27 & 14.0 & 14.0 & 13.9 & 130.5 \\
\hline 28 & 111.9 & 115.6 & 112.0 & 25.8 \\
\hline 29 & 26.1 & 24.8 & 26.0 & 21.2 \\
\hline 30 & 106.9 & 15.8 & 27.5 & 19.3 \\
\hline OMe & 51.7 & - & - & - \\
\hline
\end{tabular}

$\mathrm{H}_{2}-16$ and $\mathrm{H}-20$ to $\mathrm{H}_{3}-21$ and $\mathrm{H}_{2}-22$ (Figure 2). Analysis of $\mathrm{HMBC}$ spectra indicated correlations from $\mathrm{H}_{3}-19$ to $\mathrm{C}-1$, C-5, C-9 and C-10; from $\mathrm{H}_{3}-29$ to $\mathrm{C}-4, \mathrm{C}-5$ and $\mathrm{C}-28$; from $\mathrm{H}-7$ to $\mathrm{C}-8$; from $\mathrm{H}_{3}-18$ to $\mathrm{C}-12$, C-13, $\mathrm{C}-14$ and $\mathrm{C}-17$; from $\mathrm{H}_{3}-30$ to $\mathrm{C}-13, \mathrm{C}-16, \mathrm{C}-17$ and $\mathrm{C}-20$; from $\mathrm{H}_{3}-21$ to $\mathrm{C}-17, \mathrm{C}-20$ and $\mathrm{C}-22$; from $\mathrm{H}_{2}-22$ and $\mathrm{H}-24$ to $\mathrm{C}-23$; and from $\mathrm{H}_{3}-27$ to $\mathrm{C}-24$, $\mathrm{C}-25$ and C-26. The relative configuration of 2 was determined by analysis of a NOESY experiment, which provided correlations (Figure 2) of $\mathrm{H}-5$ to $\mathrm{H}_{2}-2 ; \mathrm{H}-28 \mathrm{Z}$ to $\mathrm{H}-9 ; \mathrm{H}-22 \mathrm{a}\left(\delta_{\mathrm{H}} 2.85\right.$ ) to $\mathrm{H}_{3}-18$ and $\mathrm{H}_{3}-21 ; \mathrm{H}_{3}-18$ to $\mathrm{H}-22 \mathrm{~b}\left(\delta_{\mathrm{H}} 2.16\right)$ and $\mathrm{H}-24 ; \mathrm{H}-24$ to $\mathrm{H}-20$ and $\mathrm{H}-22 \mathrm{~b}$. These correlations indicated the $\alpha$-orientation of $\mathrm{H}-5$ and $\mathrm{H}_{3}-30$ and the $\beta$-orientation of $\mathrm{H}-9, \mathrm{H}_{3}-18$ and $\mathrm{H}_{3}-19$. All these facts suggested that compound 2 was strongly similar to cis-sibiric acid [19]. Since the chemical shift of H-24 in cis-sibiric acid $\left(\delta_{\mathrm{H}} 6.15\right)$ was upfield of the signal for $\mathbf{1}\left(\delta_{\mathrm{H}}\right.$ $7.11), 2\left(\delta_{\mathrm{H}} 7.23\right), 6\left(\delta_{\mathrm{H}} 7.13\right)$ and $7\left(\delta_{\mathrm{H}} 7.07\right)$, this suggested 


\begin{tabular}{|c|c|c|c|c|}
\hline Position & $\delta_{H}(J$ in $H z)$ & & & \\
\hline & 1 & 2 & 3 & 4 \\
\hline 1 & $1.74, \mathrm{~m}, 1.62, \mathrm{~m}$ & $1.60, \mathrm{~m}$ & $1.73, \mathrm{~m}, 1.60, \mathrm{~m}$ & $1.85, \mathrm{~m}, 1.01, \mathrm{~m}$ \\
\hline 2 & $2.30, \mathrm{~m}$ & $2.31, \mathrm{~m}$ & $2.32, \mathrm{~m}$ & $1.93, \mathrm{~m}, 1.64, \mathrm{~m}$ \\
\hline 3 & - & - & - & $3.48, \mathrm{t}(2.4)$ \\
\hline 5 & $2.08, \mathrm{~m}$ & $2.63, \mathrm{~d}(5.4)$ & $2.08, \mathrm{~m}$ & $1.82, \mathrm{~m}$ \\
\hline 6 & $2.40, \mathrm{~m}, 2.13, \mathrm{~m}$ & $5.39, \mathrm{dd}(9.9,5.5)$ & $2.27, \mathrm{~m}, 1.99, \mathrm{~m}$ & $1.48, \mathrm{~m}, 0.77, \mathrm{~m}$ \\
\hline 7 & $5.48, \mathrm{dd}(6.2,3.1)$ & $6.22, \mathrm{~d}(10.0)$ & 5.33, br s & $1.30, \mathrm{~m}, 1.11, \mathrm{~m}$ \\
\hline 8 & - & - & - & $1.54, \mathrm{~m}$ \\
\hline 9 & $2.06, \mathrm{~m}$ & $2.43, \mathrm{~m}$ & $2.59, \mathrm{~m}$ & - \\
\hline 11 & $1.59, \mathrm{~m}, 1.40, \mathrm{~m}$ & $1.62, \mathrm{~m}$ & $1.60, \mathrm{~m}$ & $2.00, m, 1.13, \mathrm{~m}$ \\
\hline 12 & $1.77, \mathrm{~m}, 1.32, \mathrm{~m}$ & $1.65, \mathrm{~m}$ & $1.83, \mathrm{~m}, 1.67, \mathrm{~m}$ & $1.62, \mathrm{~m}$ \\
\hline 15 & $2.48, \mathrm{~m}, 2.37, \mathrm{~m}$ & $2.41, \mathrm{~m}, 2.32, \mathrm{~m}$ & $1.52, \mathrm{~m}$ & $1.31, \mathrm{~m}$ \\
\hline 16 & $1.55, \mathrm{~m}$ & $1.73, \mathrm{~m}, 1.54, \mathrm{~m}$ & $1.92, \mathrm{~m}, 1.26, \mathrm{~m}$ & $1.87, \mathrm{~m}, 1.27, \mathrm{~m}$ \\
\hline 17 & - & - & $1.54, \mathrm{~m}$ & $1.61, \mathrm{~m}$ \\
\hline 18 & $0.90, \mathrm{~s}$ & $1.16, \mathrm{~s}$ & $0.80, \mathrm{~s}$ & $1.00, \mathrm{~s}$ \\
\hline 19 & $0.92, \mathrm{~s}$ & $0.87, \mathrm{~s}$ & $0.86, \mathrm{~s}$ & $0.52, \mathrm{~d}(3.9), 0.35, \mathrm{~d}(3.9)$ \\
\hline 20 & $2.39, \mathrm{~m}$ & $2.24, \mathrm{~m}$ & $2.03, \mathrm{~m}$ & $2.02, \mathrm{~m}$ \\
\hline 21 & $0.85, \mathrm{~d}(6.4)$ & $0.80, \mathrm{~d}(6.5)$ & $0.91, \mathrm{~d}(6.2)$ & $0.88, \mathrm{~d}(6.8)$ \\
\hline 22 & $2.49, \mathrm{~m}, 2.25, \mathrm{~m}$ & 2.85, m 2.16, br d (12.3) & $2.64, \mathrm{~m} \mathrm{2.32, \textrm {m }}$ & $2.56, \mathrm{dd}(16.0,2.1), 2.24, \mathrm{dd}(16.1,10.2)$ \\
\hline 24 & $7.11, \mathrm{br} s$ & $7.23, \mathrm{br} \mathrm{s}$ & $7.15, \mathrm{~s}$ & 3.42, d (17.0) 3.36, d (17.1) \\
\hline 27 & $2.18, \mathrm{~s}$ & $2.22, \mathrm{~d}(1.0)$ & $2.21, \mathrm{~s}$ & 6.45, br s 5.73 , br s \\
\hline 28 & $4.86, \mathrm{~s}, 4.78, \mathrm{~s}$ & 4.98, br s, $4.76, \mathrm{~d}(2.4)$ & $4.88, \mathrm{~s}, 4.82, \mathrm{~s}$ & $0.95, \mathrm{~s}$ \\
\hline 29 & $1.75, \mathrm{~s}$ & $1.79, \mathrm{~s}$ & $1.80, \mathrm{~s}$ & $0.88, \mathrm{~s}$ \\
\hline 30 & $4.77, \mathrm{~s}, 4.73, \mathrm{~s}$ & $0.69, \mathrm{~s}$ & $1.04, \mathrm{~s}$ & $0.90, \mathrm{~s}$ \\
\hline OMe & $3.67, \mathrm{~s}$ & - & - & - \\
\hline
\end{tabular}

that the trans-stereoisomer was isolated instead of the cis-one (See Table 2 and Supporting Information File 1). This was further confirmed by NOESY correlation of H-24 to H-20 and $\mathrm{H}_{3}-30$, but not to $\mathrm{H}_{3}-27$. Consequently, the structure of 2 was determined as (-)-rel-(24E)-23-oxo-3,4-seco-9 $\beta H$-lanosta$4(28), 6,8(14), 24$-tetraen-3,26-dioic acid.

Compound 3, a white amorphous powder, possessed a molecular formula of $\mathrm{C}_{30} \mathrm{H}_{44} \mathrm{O}_{5}$ based on the $[\mathrm{M}+\mathrm{H}]^{+}$peak at $\mathrm{m} / \mathrm{z}$ 485.3250 (calcd 485.3262) in the positive HRESIMS, suggesting nine degrees of unsaturation. The IR spectrum implied the existence of carboxylic acid $\left(1703 \mathrm{~cm}^{-1}\right)$ and olefin $\left(1633 \mathrm{~cm}^{-1}\right)$ functionalities. The ${ }^{13} \mathrm{C}$ NMR spectroscopic data of 3 resembled those of (24E)-3,4-seco-9 $\beta H$-lanosta-4(28),7,24triene-3,26-dioic acid (12) [12] except for change at $\delta_{\mathrm{C}} 33.3$ (C-20), 19.5 (C-21), 51.9 (C-22), 202.4 (C-23), 134.4 (C-24), 139.3 (C-25), 172.8 (C-26) and 13.9 (C-27) (See Table 1 and Supporting Information File 1). The HMBC correlations from $\mathrm{H}-24$ to $\mathrm{C}-23$ indicated the presence of a ketone group at C-23 (Figure 2). This conclusion was confirmed from the downfield $\delta_{\mathrm{C}}$ of C-22 (+16.4) in comparison with 12. The relative configuration was established with the NOESY spectrum
(Figure 2). Briefly, the configuration at C-5, C-9, C-10, C-13 and $\mathrm{C}-17$ was determined by cross-peaks from $\mathrm{H}-28 \mathrm{Z}$ to $\mathrm{H}-9$; $\mathrm{H}-5$ to $\mathrm{H}_{3}-19$ and $\mathrm{H}_{3}-29 ; \mathrm{H}_{3}-18$ to $\mathrm{H}-9$ and $\mathrm{H}-20 ; \mathrm{H}_{3}-30$ to $\mathrm{H}-17$; and $\mathrm{H}_{3}-21$ to $\mathrm{H}_{2}-12$. NOESY correlation between $\mathrm{H}-24$ and $\mathrm{H}_{3}-27$ was not observed, suggesting that the geometry of the C-24,25 double bond was $E$. This was confirmed by $\delta_{\mathrm{H}}$ comparison of H-24 with that of 1, 2, 6 and 7 (See Table 2 and Supporting Information File 1). On the basis of these spectroscopic evidences, the structure of $\mathbf{3}$ was assigned as (-)-rel(24E)-23-oxo-3,4-seco-9 $\beta H$-lanosta-4(28), 7,24-triene-3,26dioic acid.

The HRESIMS of $\mathbf{4}$, isolated as a white amorphous powder, showed a pseudomolecular $[\mathrm{M}+\mathrm{H}]^{+}$ion peak at $m / z 471.3463$, corresponding to the formula $\mathrm{C}_{30} \mathrm{H}_{46} \mathrm{O}_{4}$ (calcd. 471.3469), indicating eight degrees of insaturation. The IR absorption bands at 3416,1708 and $1633 \mathrm{~cm}^{-1}$ suggested the presence of hydroxyl, carbonyl and olefin functionalities. The ${ }^{13} \mathrm{C}$ NMR and DEPT135 spectra of 4 showed signals for 30 carbons designated as five methyl; twelve methylene, including one alkene at $\delta_{\mathrm{C}}$ 130.5; five methine, including one secondary alcohol at $\delta_{\mathrm{C}} 77.1$; and eight quaternary carbons, including those at $\delta_{C} 170.8$ and 

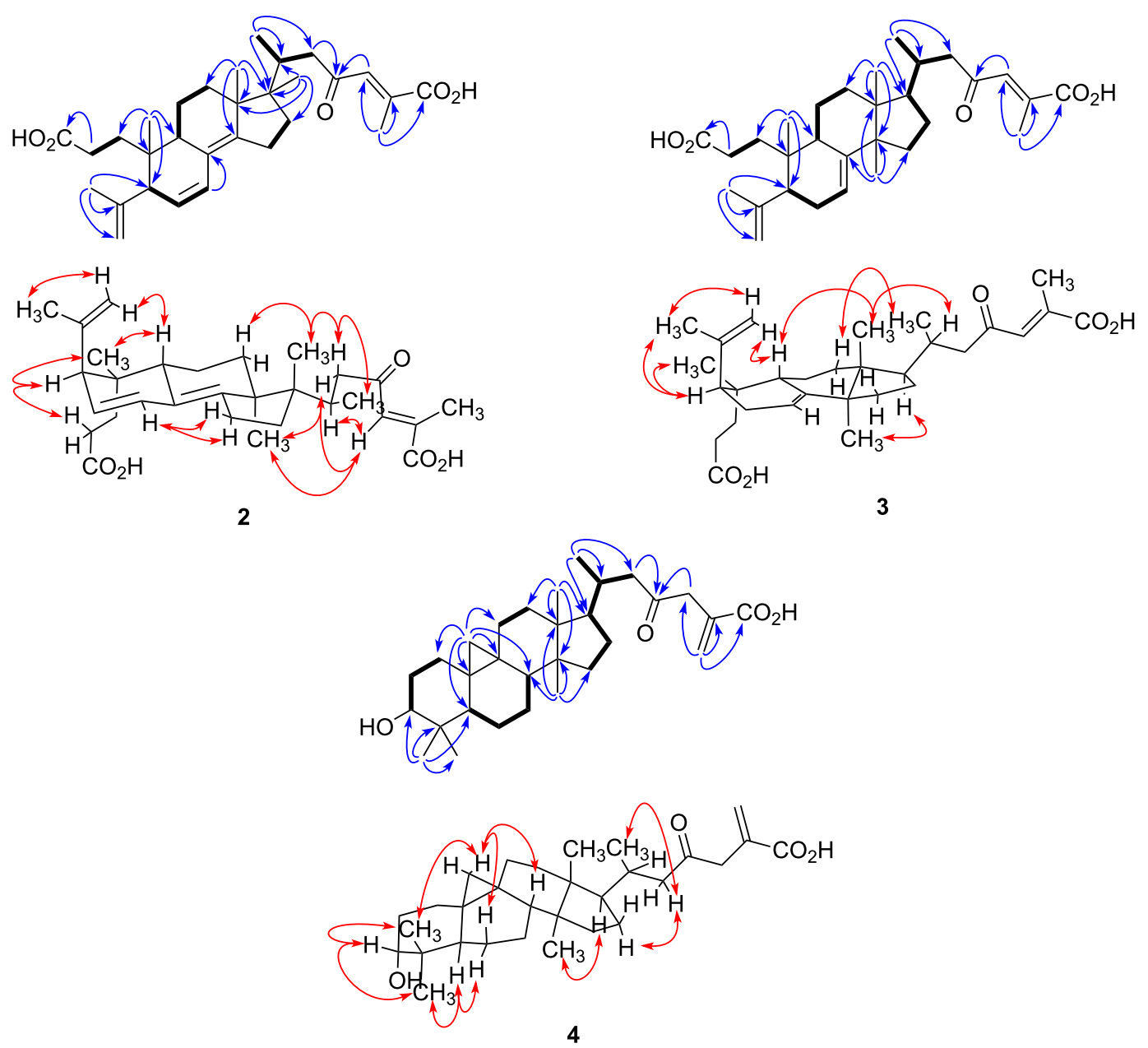

Figure 2: Selected COSY (-), HMBC (blue arrows) and NOESY (red arrows) correlations for compounds 2-4.

207.6 representing carboxylic and ketone carbonyls, respectively (Table 1). The ${ }^{1} \mathrm{H}$ NMR spectrum showed two doublets at $\delta_{\mathrm{H}}$ $0.35(J=3.9 \mathrm{~Hz})$ and $0.52(J=3.9 \mathrm{~Hz})$ characteristic of a cyclopropane ring (Table 2), suggesting that 4 is a member of the cycloartanes, which is an important triterpenic family in the genus Abies [3]. In the ${ }^{1} \mathrm{H}-{ }^{1} \mathrm{H}$ COSY spectrum, correlations between $\mathrm{H}_{2}-2$ to $\mathrm{H}_{2}-1$ and $\mathrm{H}-3 ; \mathrm{H}_{2}-6$ to $\mathrm{H}-5$ and $\mathrm{H}_{2}-7 ; \mathrm{H}_{2}-7$ to $\mathrm{H}-8 ; \mathrm{H}_{2}-16$ to $\mathrm{H}_{2}-15$ and $\mathrm{H}-17$; and $\mathrm{H}-20$ to $\mathrm{H}_{3}-21$ and $\mathrm{H}_{2}-22$ were observed (Figure 2). HMBC correlations from $\mathrm{H}_{2}-19$ to C-1, C-5, C-8, C-9, C-10 and C-11 connected together three different fragments in the vicinity of the cyclopropyl group. Other correlations between $\mathrm{H}_{3}-18$ to $\mathrm{C}-12, \mathrm{C}-13, \mathrm{C}-14$ and $\mathrm{C}-17 ; \mathrm{H}_{3}-21$ to $\mathrm{C}-17, \mathrm{C}-20$ and $\mathrm{C}-22 ; \mathrm{H}_{2}-27$ to $\mathrm{C}-24, \mathrm{C}-25$ and $\mathrm{C}-26 ; \mathrm{H}_{3}-28$ and $\mathrm{H}_{3}-29$ to $\mathrm{C}-3, \mathrm{C}-4, \mathrm{C}-5, \mathrm{C}-28$ and $\mathrm{C}-29 ; \mathrm{H}_{3}-30$ to $\mathrm{C}-8, \mathrm{C}-13, \mathrm{C}-14$ and $\mathrm{C}-15$; and $\mathrm{H}_{2}-22$ and $\mathrm{H}_{2}-24$ to $\mathrm{C}-23$ were observed and completely assigned the carbon skeleton of the molecule (Figure 2). The relative configuration was determined with the help of a 2D NOESY experiment showing correlations from $\mathrm{H}-19 \beta$ to $\mathrm{H}-6 \beta$, $\mathrm{H}-8$ and $\mathrm{H}_{3}-29$; $\mathrm{H}-5$ to $\mathrm{H}_{3}-28$ and $\mathrm{H}-6 \alpha ; \mathrm{H}_{3}-30$ to $\mathrm{H}-11 \alpha$ and $\mathrm{H}-17$; and $\mathrm{H}-22 \mathrm{~b}$ to $\mathrm{H}-20$ and $\mathrm{H}_{2}-16$ (Figure 2). The $\alpha$-orientation of the hydroxy group at C-3 was deduced from the small coupling constant of $\mathrm{H}-3$ $(J=2.4 \mathrm{~Hz})$, and from the NOESY correlations with both $\mathrm{H}_{3}-28$ and $\mathrm{H}_{3}-29$. Accordingly, the structure of compound 4 was defined as $(+)$-rel-3 $\alpha$-hydroxy-23-oxocycloart-25(27)-en-26-oic acid.

The absolute stereochemistry of the new compounds (1-4) has not been determined experimentally. However, the previously described compounds 7, 9, 10 and 11 have been shown to possess the usual configuration for triterpenes $[8,10,11]$. The structures of many other triterpenes isolated from the genus Abies were also reported with this absolute configuration according to their X-ray crystallographic data [20-22].

The structure of compound $\mathbf{8}$ was reported by Xia et al [9]. In their paper, the configuration at $\Delta^{22}$ was determined as $E$ but it was not supported by any spectroscopic data. Since ${ }^{1} \mathrm{H}$ and 
${ }^{13} \mathrm{C}$ NMR data obtained for $\mathbf{8}$ were identical to those reported by Xia within 0.01 and $0.1 \mathrm{ppm}$ respectively (see Supporting Information File 1), we supposed that both molecules were the same. However, the geometry at $\Delta^{22}$ should be assigned to $Z$ because of the clear NOESY correlation between H-22 and $\mathrm{H}-24$. Interestingly, lanostane with $E$ geometry at $\Delta^{22}$ has never been isolated so far. Moreover, triterpenes with this kind of side chain bearing an $E$ configuration for $\Delta^{22}$ have only been reported by Guo et al $[23,24]$. During their work on Schisandra spp., they isolated many nortriterpenes having both $\Delta^{22}$ configurations. A statistical analysis of the ${ }^{1} \mathrm{H}$ chemical shift for H-22 and H-24 was conducted: for $E$-configured $\Delta^{22}$, $\delta_{\mathrm{H}}$ are $5.9 \pm 0.2$ and $7.8 \pm 0.1$ while for $Z$-configured $\Delta^{22}, \delta_{\mathrm{H}}$ are $5.3 \pm 0.1$ and $7.2 \pm 0.2$, respectively. Since $\delta_{\mathrm{H}}$ measured for compound $\mathbf{8}$ was 4.98 and 6.97, it should be assigned as (22Z)3,4-seco-9ßH-lanosta-4(28),7,22,24-tetraen-23,26-olid-3-oic acid.

The isolates were evaluated in vitro for their cytotoxic activities against two human cancer cell lines, namely lung carcinoma (A549) and colon adenocarcinoma (DLD-1), as well as against one healthy cell line (WS1) using the resazurin reduction test [25]. Etoposide was used as a positive control $\left(\mathrm{IC}_{50} \leq 1.0 \mu \mathrm{M}\right)$. None of the compounds were found to be active ( $\left.\mathrm{IC}_{50}>25 \mu \mathrm{M}\right)$ with the exception of abiesonic acid (6), which showed a weak cytotoxic activity against A549 $\left(\mathrm{IC}_{50}=22 \mu \mathrm{M}\right)$. The antibacterial activity of isolated compounds was also evaluated in vitro against $E$. coli and $S$. aureus using the microdilution assay [26] with gentamycin as a positive control (MIC $<0.1 \mu \mathrm{g} / \mathrm{mL}$ ). No activity was observed for all the tested compounds (MIC $\geq 50 \mu \mathrm{M}$ ) except for triterpenoids 1 and $\mathbf{4}$, which were weakly active against $S$. aureus $(\mathrm{MIC}=25 \mu \mathrm{M})$.

\section{Supporting Information}

\section{Supporting Information File 1}

Experimental procedures, product characterization and ${ }^{1} \mathrm{H}$ and ${ }^{13} \mathrm{C}$ spectra for compounds $\mathbf{1}-\mathbf{1 8}$.

[http://www.beilstein-journals.org/bjoc/content/ supplementary/1860-5397-9-150-S1.pdf]

\section{Acknowledgements}

We acknowledge "Chaire de Recherche sur les Agents Anticancéreux d'Origine Végétale" and NSERC for funding, and Catherine Dussault for biological assessment. The photograph from our graphical abstract is from Robert H. Mohlenbrock@USDA-NRCS PLANTS Database / USDA NRCS. 1995. Northeast wetland flora: Field office guide to plant species. Northeast National Technical Center, Chester.

\section{References}

1. Mabberley, D. J. Mabberley's plant-book: a portable dictionary of plants, their classification and uses, 3rd ed.; Cambridge University Press: Cambridge, 2008; pp $1 \mathrm{ff}$.

2. Takahashi, T. J. Pharm. Soc. Jpn. 1938, 58, 888-901.

3. Yang, X.-W.; Li, S.-M.; Shen, Y.-H.; Zhang, W.-D. Chem. Biodiversity 2008, 5, 56-81. doi:10.1002/cbdv.200890015

4. Herrick, J. W.; Snow, D. R. Iroquois medical botany; Syracuse University Press: Syracuse, NY, 1995; p 278.

5. Pichette, A.; Larouche, P.-L.; Lebrun, M.; Legault, J. Phytother. Res. 2006, 20, 371-373. doi:10.1002/ptr.1863

6. Lavoie, S.; Legault, J.; Gauthier, C.; Mshvildadze, V.; Mercier, S.; Pichette, A. Org. Lett. 2012, 14, 1504-1507. doi:10.1021/ol300237f

7. Shang, N.; Guerrero-Analco, J. A.; Musallam, L.; Saleem, A.; Muhammad, A.; Walshe-Roussel, B.; Cuerrier, A.; Arnason, J. T.; Haddad, P. S. J. Ethnopharmacol. 2012, 141, 1051-1057. doi:10.1016/j.jep.2012.04.002

8. Roshchin, V. I.; Raldugin, V. A.; Baranova, R. A.; Pentegova, V. A. Chem. Nat. Compd. 1986, 22, 613-614. doi:10.1007/BF00599284

9. Xia, J.-H.; Zhang, S.-D.; Li, Y.-L.; Wu, L.; Zhu, Z.-J.; Yang, X.-W.; Zeng, H.-W.; Li, H.-L.; Wang, N.; Steinmetz, A.; Zhang, W.-D. Phytochemistry 2012, 74, 178-184. doi:10.1016/j.phytochem.2011.11.011

10. Wada, S.-i.; lida, A.; Tanaka, R. J. Nat. Prod. 2002, 65, 1657-1659. doi:10.1021/np020282b

11. Raldugin, V. A.; Gatilov, Y. V.; Rybalova, T. V.; Rashkes, Y. V. Chem. Nat. Compd. 1986, 22, 645-651. doi:10.1007/BF00598342

12. Kim, H. J.; Choi, E. H.; Lee, I.-S. Phytochemistry 2004, 65, 2545-2549. doi:10.1016/j.phytochem.2004.07.007

13. Yang, X.-W.; Li, S.-M.; Feng, L.; Shen, Y.-H.; Tian, J.-M.; Liu, X.-H.; Zeng, H.-W.; Zhang, C.; Zhang, W.-D. Tetrahedron 2008, 64, 4354-4362. doi:10.1016/j.tet.2008.02.069

14. Abad, A.; Arnó, M.; Peiró, M.; Zaragoza, R. J. Tetrahedron 1991, 47, 3829-3844. doi:10.1016/S0040-4020(01)80907-8

15. Zhao, Y.-X.; Zhou, L.; Guo, L.; Luo, X.-D.; Zhou, J. J. Asian Nat. Prod. Res. 2005, 7, 259-264. doi:10.1080/10286020410001690163

16. Alvarez-Manzaneda, E. J.; Chahboun, R.; Guardia, J. J.; Lachkar, M.; Dahdouh, A.; Lara, A.; Messouri, I. Tetrahedron Lett. 2006, 47, 2577-2580. doi:10.1016/j.tetlet.2006.02.037

17. Wahlberg, I.; Vogt, C.; Wallin, I.; Nishida, T.; Enzell, C. R. Acta Chem. Scand., Ser. B 1982, 36, 573-576. doi:10.3891/acta.chem.scand.36b-0573

18. Wahlberg, I.; Karlsson, K.; Curvall, M.; Nishida, T.; Enzell, C. R. Acta Chem. Scand., Ser. B 1978, 32, 203-215. doi:10.3891/acta.chem.scand.32b-0203

19. Shevtsov, S. A.; Raldugin, V. A. Chem. Nat. Compd. 1989, 25 , 182-187. doi:10.1007/BF00598407

20. Li, Y.-L.; Gao, Y.-X.; Yang, X.-W.; Jin, H.-Z.; Ye, J.; Simmons, L.; Wang, N.; Steinmetz, A.; Zhang, W.-D. Phytochemistry 2012, 81, 159-164. doi:10.1016/j.phytochem.2012.05.032

21. Yang, X.-W.; Li, S.-M.; Wu, L.; Li, Y.-L.; Feng, L.; Shen, Y.-H.; Tian, J.-M.; Tang, J.; Wang, N.; Liu, Y.; Zhang, W.-D. Org. Biomol. Chem. 2010, 8, 2609-2616. doi:10.1039/c001885f 22. Li, Y.-L.; Yang, X.-W.; Li, S.-M.; Shen, Y.-H.; Zeng, H.-W.; Liu, X.-H.; Tang, J.; Zhang, W.-D. J. Nat. Prod. 2009, 72, 1065-1068. doi: $10.1021 / \mathrm{np} 800790 \mathrm{~h}$

23. Wang, J.-R.; Kurtán, T.; Mándi, A.; Guo, Y.-W. Eur. J. Org. Chem. 2012, 5471-5482. doi:10.1002/ejoc.201200557 
24. He, F.; Li, X.-Y.; Yang, G.-Y.; Li, X.-N.; Luo, X.; Zou, J.; Li, Y.; Xiao, W.-L.; Sun, H.-D. Tetrahedron 2012, 68, 440-446. doi:10.1016/j.tet.2011.11.026

25. O'Brien, J.; Wilson, I.; Orton, T.; Pognan, F. Eur. J. Biochem. 2000, 267, 5421-5426. doi:10.1046/j.1432-1327.2000.01606.x

26. Banfi, E.; Scialino, G.; Monti-Bragadin, C. J. Antimicrob. Chemother. 2003, 52, 796-800. doi:10.1093/jac/dkg439

\section{License and Terms}

This is an Open Access article under the terms of the Creative Commons Attribution License

(http://creativecommons.org/licenses/by/2.0), which permits unrestricted use, distribution, and reproduction in any medium, provided the original work is properly cited.

The license is subject to the Beilstein Journal of Organic Chemistry terms and conditions:

(http://www.beilstein-journals.org/bjoc)

The definitive version of this article is the electronic one which can be found at: doi:10.3762/bjoc. 9.150 